\title{
MENGELOLA CAGAR BUDAYA DI WILAYAH RAWAN BENCANA APAKAH INDONESIA SUDAH SIAP?
}

\author{
Managing Heritage Sites in Disaster-Prone Zone \\ Is Indonesia Ready?
}

\author{
Supratikno Rahardjo \\ Departemen Arkeologi \\ Fakultas Ilmu Budaya Universitas Indonesia \\ E-mail: supratikno.rahardjo@gmail.com
}

\begin{abstract}
Absract
Major disasters have long occurred in the territory of Indonesia. The loss of life, property, and cultural wealth has also been felt. But awareness to anticipate the impact of disasters, especially on cultural heritage, was not felt until entering the early decades of the 2000s. It was only after successive major disasters over the past two decades, namely tsunamis, earthquakes, and volcanoes erupting in several parts of Indonesia, that disaster mitigation efforts began to be encouraged. Some disasters are smaller in scale but more often the frequency of events, namely fires and floods that damage cultural reserves, adds to concerns that the wealth of cultural reserves will be further lost. Such traumatic experiences mostly result in immediately visible damage. But another source of problems that seem to be a priority has not been prepared, namely awareness to overcome them through mitigation so that disaster risks can be reduced and the impact of disasters can be minimized. Without making serious efforts to take these precautions, the Indonesian nation will be threatened with losing its precious cultural heritage, both for current and future generations.
\end{abstract}

Keywords: disaster, heritage site, archaeology

\begin{abstract}
Abstrak
Bencana-bencana besar sejak lama terjadi di wilayah Indonesia. Korban-korban nyawa, harta dan kekayaan budaya juga telah dirasakan. Namun kesadaran untuk mengantisipasi dampak bencana, khususnya terhadap cagar budaya, belum terasa hingga memasuki awal dekade tahun 2000an. Baru sesudah terjadi bencana-bencana besar secara beruntun selama hampir dua dekade terakhir, yaitu tsunami, gempa bumi, dan gunung meletus di beberapa wilayah Indonesia, upaya-upaya mitigasi bencana mulai digalakkan. Beberapa bencana yang lebih kecil skalanya namun lebih sering frekuensi kejadiannya, yaitu kebakaran dan banjir yang merusak cagar budaya, menambah kekhawatiran bahwa kekayaan cagar budaya akan semakin hilang. Pengalaman-bengalaman traumatis tersebut sebagian besar mengakibatkan kerusakan yang langsung terlihat dengan jelas. Namun sumber permasalahan lain yang tampaknya harus dijadikan prioritas justru belum disiapkan, yaitu kesadaran untuk mengatasinya melalui mitigasi agar resiko bencana dapat dikurangi dan dampak bencana dapat diminimalisasi. Tanpa melakukan upaya yang sungguh-sungguh untuk melakukan tindakan pencegahan ini bangsa Indonesia akan terancam kehilangan warisan budayanya yang sangat berharga, baik bagi generasi saat ini maupun mendatang.
\end{abstract}

Kata kunci: bencana, cagar budaya, arkeologi, 


\section{PENDAHULUAN}

Indonesia merupakan wilayah yang berada di pertemuan empat lempeng tektonik, yaitu benua Asia, Australia, Samudera Hindia, dan Samudera Pasifik. Di bagian selatan dan timur Indonesia terdapat rangkaian gunun api yang memanjang dari pulau Sumatera, Jawa, lalu ke Nusa Tenggara dan Sulawesi. (Asman, Aulia dkk, 2020, h.34). Di samping itu Indonesia dikenal memiliki gunung api aktif terbanyak di dunia, yaitu lebih dari 30\%. Terdapat 127 gunung berapi aktif melingkari tanah nusantara. Hingga saat ini gunung api aktif di Indonesia dikelompokkan hanya berdasarkan sejarah letusannya, yaitu tipe A (79 buah), adalah gunung api yang pernah meletus sejak tahun 1600, tipe B (29 buah) adalah yang diketahui pernah meletus sebelum tahun 1600, dan tipe C (21 buah) adalah lapangan solfatara dan fumarola (Pratomo 2006: 209).

Tantangannya sangat besar mengingat jumlah gunung api aktif (tipe A) di Indonesia mencapai 79 gunung dengan penyebaran mencakup Sumatera (13), Jawa (21), Bali (2), Lombok (1), Sumbawa (2), Flores (16), Laut Banda (8), Sulawesi (6), Kepulauan Sangihe (5), dan Halmahera (5). Berdasarkan kondisi geografis itu, Indonesia memiliki potensi besar menjadi negeri rawan bencana alam. Dengan total gunung berapi terbanyak di Pulau Jawa maka berarti terdapat lebih dari 120 juta orang hidup dalam ancaman letusan gunung berapi. Hasil kajian terhadap sebagian dari gunung api aktif tersebut di atas memperlihatkan perbedaan karakter erupsi yang secara langsung berhubungan dengan potensi ancaman bahaya letusannya. Kedekatan warga dengan lokasi gunung berapi telah terbukti fatal karena lebih dari 150.000 jiwa tewas akibat meletusan gunung berapi di seluruh nusantara dalam kurun waktu 500 tahun terakhir. Angka ini merupakan rekor dunia (Wardyaningrum 2014, h. 180).

Gambara umum tentang indeks risiko bencana Indonesia dapat dilihat dalam peta yang dikeluarkan oleh BNPB tahun 2018 (Gambar 1). Dari peta tersebut dapat diketahui bahwa sebagian besar wilalayah Indonesia memiliki indeks resiko bencana yang tinggi. Hal ini tidak bertentantang dengan fakta geologis dan Vulkanologis yang telah umum diketahui bahwa wilayah Indonesia memang berada di sepanjang cincin api. 


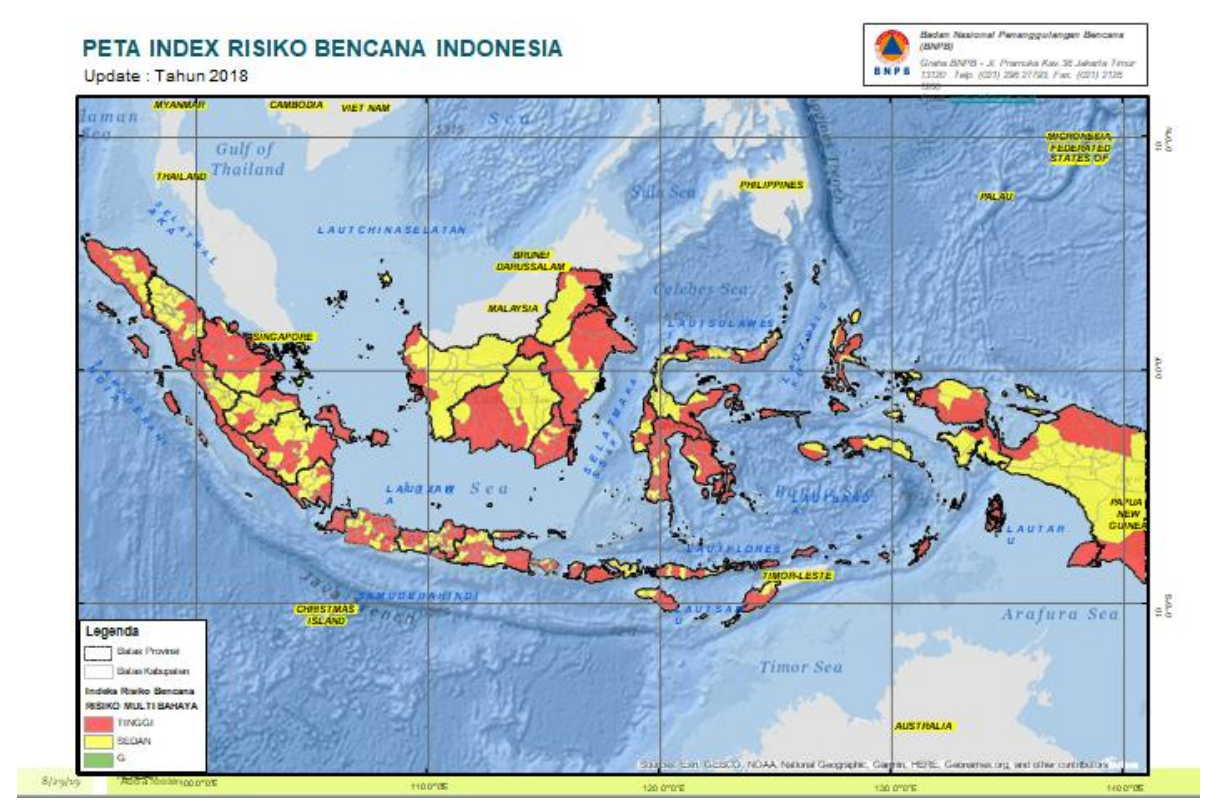

Gambar 1. Peta Index Risisko Bencana di Indonesia (Sumber: Banton, 2019).

Jika peta risiko bencana itu dilihat dengan lebih seksama, jelas terlihat bahwa wilayah-wilayah dengan risiko bencana yang tinggi adalah juga pusat-pusat aktivitas dan kehidupan manusia, baik pada masa kini maupun pada masa lampau. Tidak sulit untuk menunjukan bukti berdasarkan sejarah kebudayaan atau peradaban bangsa Indonesia, bahwa sebagian besar pusat-pusat kehidupan yang berlangsung sejak zaman prasejarah hingga kini, sesungguhnya tidak mengalami pergeseran ruang yang berarti. Terlebih lagi untuk wilayah pulau Jawa. Meskipun pulau ini relatif kecil, namun tempat ini merupakan pusat interaksi manusia sejak ratusan ribu tahun yang lalu, bahkan lebih tua lagi (cf. Maeno, Fukashi dkk, 2019). Ajaibnya - ini fakta lain yang istimewa: bahwa bangsa Indonesia yang hidup di tengah "cincin api" ini masih tetap eksis hingga saat ini. Memiliki warisan budaya yang sangat kaya dan mengagumkan. Saat ini memiliki jumlah penduduk lima terbesar dunia. Apa artinya? Ternyata manusia Indonesia bisa tetap lestari bersama dengan rentetan bencanabencana besar. Kearifan lokal apa atau rahasia apa dibalik keajaiban ini? Jawabannya mungkin bisa dilacak melalui warisan budaya kita yang masih tersedia hingga kini.

Sebagian pertanyaan tadi mungkin bisa dijawab oleh fakta ajaib lainnya, yaitu bahwa letusan gunung api juga membawa berkah karena mengakibatkan wilayah sekitar gunung api subur untuk pertanian. Oleh karena itu, di wilayah-wilayah yang sejak dahulu kala menjadi pusat bencana letusan gunung api, hingga kini merupakan daerah yang selalu padat penduduk. Jika kita mengambil kasus di pulau Jawa, daerah-daerah di wilayah tersebut terkenal dengan peninggalan peradaban yang tinggi dengan monumen-monumennya yang megah, terutama di Jawa Tengah di mana Gunung Merapi selalu mendampingi keruntuhan dinasti-dinasti Mataram Kuno dan di Jawa Timur dengan Gunung Kelud yang diduga ikut meruntuhkan 
peradaban besar yang tumbuh di wilayah tersebut (Schrieke 1958; Geertz 1983, Hidayati, Sri dkk, 2009).

\section{PEMBAHASAN}

\section{Kajian Kebencanaan dalam Arkeologi dan Pelestarian Cagar Budaya}

Data kebencanaan telah lama dijadikan sumber informasi untuk menjelaskan berbagai kejadian pada masa lampau. Sumber-sumber tersebut diperoleh dari prasasti, naskah kuno, arsip, lukisan seniman, lapisan tanah bekas letusan gunung api. Data itu baik digunakan secara tersendiri maupun penggabungannya sering dimanfaatkan untuk merekonstruksi kehiduan masa lalu. Catatan tertua tentang hancurnya desa yang disebabkan karena lestusan gunung apa dalam prasasti Rukam (907 M) dihubungkan dengan penemuan situs pemukiman yang terkubur di bawah tanah di desa Liangan (Abbas). Catatan sejarah tahun $1006 \mathrm{M}$ dan tanda geologis Gunung Merapi yang diyakini meletus pada tahun itu, dianggap sebagai penyebab berpindahnya pusat kerajaan Mataram Kuno Jawa Tengah ke Jawa Timur (cf. Schrieke 1958). Demikian juga catatan kitab Pararaton yang menyebutkan adanya sejumlah letusan gunung api di Jawa Timur dianggap sebagai penyebab runtuhnya kerajaan Majapahit (Bandono 1980). Temuan arkeologi berupa sisa-sisa pemukiman kuno yang hangus dan jasad manusia di Sumbawa dianggap sebagai bukti bahwa wilayah kerajaan kuno yang pernah tumbuh di tempat itu runtuh sebagai akubat dari dahsyat Gunung Tambora (Wibisono 20). Pada masa yang jauh lebih tua lagi, yaitu sekitar 75.000 tahun yang lalu, terjadi letusan yang maha dahsyat di Sumatera yang sisa-sisanya kini dikenal sebagai Danau Toba, dianggap sebagai penyebab migrasi homo sapien dari Afrika terlambat sampai Asia. Sebagaimana diketahui awal migrasi telah berlangsung sejak 120.000 yang lalu, tetapi sampai di Asia baru terjadi sesudah peristiwa dahsyat tersebut (Kompas, Liputan Khusus, 2011. Pada periode berikutnya, zaman es terakhir, ditandai dengan naiknya permukaan air laut yang menyebabkan Dataran Sunda tenggelam dan penduduknya menyebar ke barbagai belahan dunia (Oppenheimer 2010). Tidak semua rekonstruksi sejatrah itu memuaskan, tetapi para ahli memiliki kayakinan bahwa peristiwa-peristiwa kebencanaan masa lalu benar-benar terjadi, dan banyak mengakibatkan kesengsaraan umat manusia.

Catatan sejarah kebencanaan di Indonesia sebelum abad ke-16 sangat sedikit, tetapi sesudah periode itu kita mengetahui bahwa peristiwa bencana alam memang sering terjadi. Hingga kini peristiwa bencana alam tampaknya semakin sering terjadi. Bagi arkeologi, relavansi kebencanaan pada saat ini masih tetap berguna untuk memahami kejadian-kejadian penting masa lalu, namun kini memiliki fungsi tambahan, yaitu untuk melakukan pelestarian terhadap tinggalan masa lampau yang kini telah dinyatakan sebagai warisan yang penting yang dikenal sebagai cagar budaya. Perhatian terhadap kebencanaan terhadap warisan umat manusia yang harus dilindungi sebenarnya telah lama menjadi perhatian lembaga internasional yang salah 
satunya mengurusi kebudayaan, yaitu UNESCO. Di antara dokumen-dokumen yang tersebut dihasilkan dalam bentuk konvensi-konvensi, deklarasi dan panduan-panduan yang terbut sejak tahun 1954, khususnya tentang konflik bersenjata, dan pada tahuntahun sesudah 1980-an, terutama berkaitan dengan gempa bumi, letusan gunung apa dan juga kebakaran.

Meskipun Indonesia merupakan anggota UNESCO sejak tahun 1950 dan telah meratifikasi konvensi perlindungan warisan budaya dan alam dunia tahun 1989, namun upaya mengadaptasi kebijakan-kebijakan UNESCO yang berkaitan dengan penanggulangan bencana cagar budaya ke dalam kebijakan nasional, terhitung lambat, mengingat wilayah Indonesia merupakan salah satu kawasan yang memiliki warisan budaya dunia dengan indeks risiko bencana yang tinggi di dunia (Gambar 2).

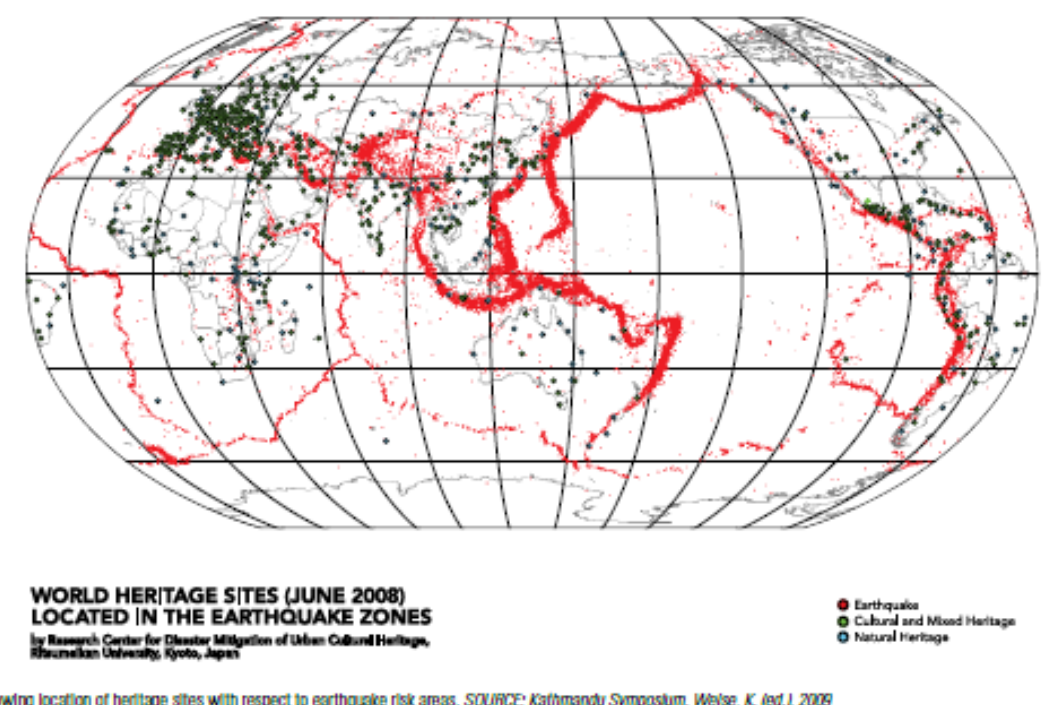

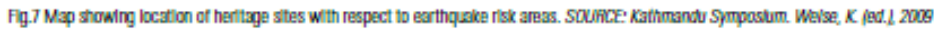

Gambar 2. Lokasi Warisan Dunia di Zona Gempa (Sumber: Walse, K (Ed), 2009).

Bencana-bencana besar yang berturut-turut terjadi sesudah tahun 2000, tidak saja menghancurkan harta, benda, nyawa manusia dan infrastruktur, tetapi juga cagar budaya, terutama yang terjadi di Aceh (2004), Yogyakarta (2006), Padang (2007, 2009). Namun laporan yang paling intensif tentang bencana yang terkait dengan cagar budaya, baru yang baru muncul setalah gempa besar di Yogyakarta. Cukup cepat tanggapannya karena laporan khusus itu dapat diselesaikan pada tahun yang sama (Balai Pelestarian Peninggalan Purbakala Jawa Tengah, 2006). Berita yang lebih umum kaena menyangkut bencana nasional juga dimuat dalam Koran nasional dan dimuat lagi sebagai kumpulan tulisan yang diterbitkan oleh Kompas pada tahun 2011 (Kompas 2011, cf. Laksono; Genthong; Isworo; Harijono; Damayanti; Damardono, dan Wahyudi, 2011). Tulisan-tulisan tentang kebencanaan yang berkaitan dengan pelindungan cagar budaya semakin mendapat perhatian pada tahuntahun berikutnya, baik yang berkaitan dengan gempa bumi, tsunami, banjir, kerusuhan sosial, dan kebakaran, terutama yang terjadi di kawasan pemukiman kota 
dan perkampungan-perkampungan tradisional (Antar, 2018, Oesman, 2018, Panjaitan 2019).

Adanya kesadaran bahwa bencana dapat menimbulkan kehancuran maka fenomena itu harus kaji dan dipahami. Namun karena kejadiannya tidak dapat diprediksi, maka upaya yang paling utama adalah melakukan mitigasi bencana. Tujuan mitigasi adalah untuk mengurangi dampak bencana, yaitu mengurangi angka korban nyawa manusia dan hewan, kehancuran harta benda, infrastruktur dan saranasarana hidup lainnya. Melalui tindakan mitigasi kita juga bisa menyiapkan diri untuk menghadapi ancaman bencana yang mungkin akan kembali datang. Sebagaimana kita ketahui bencana alam bisa datang kapan saja tanpa sepenuhnya kita sadari. Mitigasi yang dilakukan pada saat tidak ada bencana memungkinkan upaya untuk menyiapkan pemberdayaan sumber daya manusia melalui pelatihan agar mereka memiliki pemahaman tentang gejala bencana, meningkat kesadarannya terhadap risiko bencana dan dapat mengantisipasi dengan membangun sarana-sarana fisik untuk mengantisipasi berbagai risiko akibat bencana sambil mereka tetap dapat menjalani hidup di tengah bencana.

\section{Manajemen Risiko Bencana Cagar Budaya dan Sistem Manajemen Bencana Nasional}

Mengapa penting bagi kita melakukan mitigasi bencana cagar budaya? Jawabannya adalah karena kita ingin menjadi bangsa yang tidak hanya mampu menghargai nyawa manusia dan harta benda yang jadi miliknya, tetapi juga menghargai warisan-warisan kemanusiaan yang harus kita pelihara dan kita jaga, yaitu cagar budaya. Kehancuran cagar budaya, sebagaimana korban bencana berupa nyawa, harta benda dan infrastruktur, semuanya meninggalkan trauma dan luka. Melalui upaya mitigasi, semua risiko itu bisa ditekan hinggi ke batas minimum yang bisa dicapai oleh kapasitas manusia saat ini. Perkembangan ilmu pengetahuan dan teknologi modern yang telah kita kuasai saat ini memberi kemungkinan untuk mencegah terjadinya risiki bencana secara maksimal.

Perhatian pemerintah terhadap bencana sebenarnya sudah muncul sejak awal kemerdekaan, namun awalnya masih berfokus pada isu-isu sektoral. Dalam perkembangannya kemudian berbagai bencana muncul, baik yang bersifat alam maupun sosial sehingga dibentuk beberapa kali badan penanganan bencana dengan lingkup yang semakin luas (cf. https://bnpb.go.id/sejarah-bnpb). Kini Indonesia telah memiliki lembaga penanggulangan bencana dengan cakupan luas dan lebih terintegrasi. Dikoordinasikan oleh pejabat setingkat menteri yang khusus menangani berbagai masalah kebencanaan. Lembaga tersebut bernama Badan Nasional Penanggulangan Bencana (BNPB) yang dibentuk pada tahun 2008 menyusul dikeluarkannya UU RI No. 24 tahun 2007 tentang Penanggulangan Bencana. Merespons UU ini dan pembentukan BNPB mendorong sejumlah pihak mengembangkan program-program spesifik yang mengkaitkannya dengan sumber bencana, misalnya penanggulangan kebakaran, banjir, gempa bumi, dll. Di samping 
itu juga terdapat program-program yang berkaitan dengan penanganan bencana di tempat kerja, di rumah sakit dll.

Di bidang pelestarian Cagar Budaya, komitmen penanganan risiko bencana belum begitu terasa di lembaga-lembaga terkait. Meskipun demikian, di daerahdaerah yang memiliki pengalaman bencana relative intensif, misalnya Yogyakarta dan Jawa Tengah, kesiapan itu sudah tampak, namun belum menjadi bagian dari kebijakan nasional.

Komitmen awal untuk melakukan upaya pencegahan risiko bencana cagar budaya sebenarnya telah menjadi perhatian UNESCO. Convensi yang menangani secara khusus penanggulangan bencana cagar budaya akibat konflik bersenjata telah dibuat pada tahun 1954, yaitu Convention for the protection of Cultural Property in the Event of Armed Conflict. Sedangkan panduan-panduan lain umumnya memuat penanganan kerusakan yang prosesnya relative pelan dan bersifat kumulatif. Terbitan-terbitan yang berkaitan dengan jenis bencana yang lebih besar dan berlangsung cepat baru mulai muncul sejak tahun 1993 hingga memasuki tahun 2000-an, khususnya yang berkaitan dengan gempa bumi, tsunami maupun perubahan iklim (cf. UNESCO, 2010). Di samping itu muncul juga deklarasi Tokyo (1997) dan Deklarasi Quibec (1998) tentang "Risk Preparedness". Namun baru tahun 2010 UNESCO sendiri mengeluarkan terbitan berupa buku manual tematik (world heritage manual resource) tentang manajemen risiko bencana, yaitu Managing Disaster Risks for World Heritage. Kemudian ICCROM mengekuarkan buku panduan khusus untuk menajemen risiko warisan dunia pada tahun 2016, yaitu $A$ Guide to Risk management of World Cultural heritage. Menyusul terbitnya berbagai tulisan tentang manajemen risiko bencana cagar budaya tersebut, sejumlah Negara anggota UNESCO membuat panduan serupa untuk kepentingan negaranya masingmasing, di antaranya adalah India (2017).

Beberapa tahun lalu upaya awal untuk mebangun sistem mitigasi risiko bencana di Indonesia sudah dimulai, namun baru sekitar dua tahun terakhir mulai ditangani secara lebih intensif. Progrrm penyusunan pedoman yang semula diberi judul Mitigasi Bencana Cagar Budaya mengalami penyempurnaan dengan memasukkan semua bentuk penanggulangan yang mencakup tahapan pra bencana, saat bencana dan pasca bencana. Dengan melibatkan BNPB, cakupannya menjadi lebih lengkap dan judul dokumennya menjadi Cagar Budaya Tangguh Bencana. Sekarang sudah sampai tahap uji petik melalui FGD sebelum nantinya disahkan dan dijadikan peraturan menteri (komunikasi pribadi dengan Sri Patmiarsi, Kapokja Pelindungan Dit Pelindungan Kebudayaan, 2020).

Apakah ini kebutuhan mendesak? Jika kita melihat kondisi geografi kita dan indeks risiko bencananya yang tinggi, seharusnya ini menjadi prioritas. Negara India yang kondisi kawasan dan risiko bencananya tidak setinggi Indonesia telah membuat kebijakan nasional untuk menanganan cagar budaya sejak tahun 2017. Dokumennya ditandatangi langsung oleh Perdana Menteri Narendra Modi, sehingga mempunya kekuatan untuk diimplementasikan di seluruh India. Ini merupakan bentuk komitmen 
untuk mengubah paradigm lama yang semula bersifat reaktif dan ditanggapi langsung ketika terjadi bencana ke pendekatan proaktif dengan cara melakukan mitigasi sehingga dapat menekan risiko kerugian yang lebih besar.

Berdasarkan kegiatan penaggulangannya, siklus bencana di Indonesia dibagi ke dalam empat bagian, yaitu (1) tanggap darurat yang dilakukan segera saat bencana terjadi untuk penyelamatan korban manusia; (2) rehabilitasi dilakukan sesudah bencana untuk memulihkan fungsi-fungsi dasar kehidupan masyarakat, (3) rekonstruksi untuk memulihkan kondisi sebagaimana semula, dan (4) pencegahan bencana yang dimaksudkan untuk mengurangi risiko bencana yang mungkin akan terjadi kembali pada masa yang akan datang. Untuk memahami keseluruhan siklus bencana dan jenis kegiatan yang dilakukan di setiap tahap dapat dilihat bagan berikut yang dijadikan kerangka oleh pemerintah India (Gambar 3):

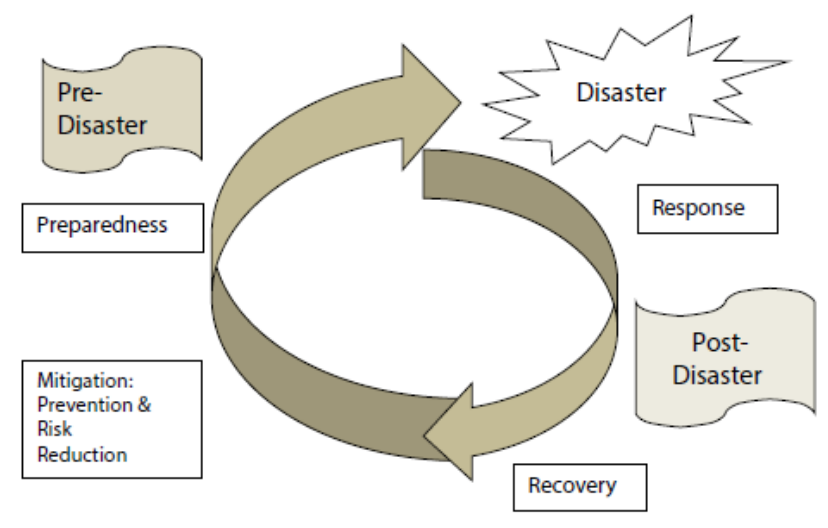

Gambar 3. Siklus Bencana (Sumber: Gov. of India, 2017).

Bagan ini memperlihatkan kegiatan penanggulangan segera setelah terjadinya bencana, yaitu melakukan tindakan tanggap darurat (response). Sesudah bencana dilakukan tindakan penanganan pasca bencana yang meliputi rehabilitasi dan rekonstruksi (recovery). Selanjutnya dilakukan upaya-upaya mitigasi, pencegahan \& pengurangan risiko (mitigation \& risk reduction) dan melakukan tindakan-tindakan persiapan untuk menghadapi risiko bencana bila muncul potensi terjadinya bencana (preparedness). Dalam tulisan ini pembahasan tentang manajemen risiko bencana hanya akan memusatkan perhatian pada salah satu bagian dari rangkaian manajemen bencana, yaitu mitigasi risiko bencana yang dilakukan pada saat tidak terjadi bencana, atau ketika bencana telah berlangsung, atau sebelum bencana baru terjadi lagi.

\section{Mitigasi Risiko Bancana Cagar Budaya}

Kini semakin disadari bahwa cagar budaya di Indonesia semakin terbuka dari ancaman bencana. Kasus-kasus bencana tsunami yang terjadi di Aceh, Padang dan 
Yogyakarta telah memberi pelajaran bahwa bencana tidak hanya berakibat pada objek-objek berupa benda cagar budaya yang bergerak, tetapi juga terhadap jenisjenis cagar budaya lain, yaitu bangunan, struktur, situs-situs, dan kawasan-kawasan cagar budaya, baik di pedesaan maupun di perkotaan. Termasuk di dalamnya adalah koleksi yang berada di gedung-gedung museum. Oleh karena itu perlu dilakukan pendekatan penaggulangan secara terintegrasi. Keterbatasan sumber daya manusia dan pendanaan juga menuntut adanya koordinasi antara para profesional dan lembaga-lembaga yang mengurusi situs-situs, museum, voluntir dan lembagalembaga terkait lainnya.

Untuk memahami persoalan lebih jelas, disini perlu lebih dahulu dijelaskan beberapa definisi yang terkait dengan manajemen bencana. Pengertian diambil dari rumusan Pasal 1, UU No. 24 tahun 2007 tentang Penanggulangan Bencana, khusunya istilah-istilah bencana, ancaman bencana, risiko bencana, mitigasi, pencegahan bencana. Disamping itu ditambahkan istilah lain yang diperlukan untuk memahami cagar budaya, yaitu kerentanan (vurnerability).

Bencana: adalah "peristiwa atau rangkaian peristiwa yang mengancam dan mengganggu kehidupan dan penghidupan masyarakat yang disebabkan baik oleh faktor alam, faktor non alam maupun factor manusia sehingga mengakibatkan timbulnya korban jiwa manusia, kerusakan lingkungan, kerugian harta benda dan dampak psikologis".

Adapun cakupan bencana dikelompokkan menjadi tiga kategori, yaitu bencana alam, bencana nonalam, dan bencana social. Bencana alam adalah bencana yang diakibatkan oleh peristiwa atau serangkaian peristiwa yang disebabkan oleh alam antara lain berupa gempa bumi, tsunami, gunung meletus, banjir, kekeringan, angin topan, dan tanah longsor. Bencana nonalam adalah bencana yang diakibatkan oleh peristiwa atau rangkaian peristiwa nonalam yang antara lain berupa gagal teknologi, gagal modernisasi, epidemi, dan wabah penyakit. Sedangkan bencana sosial adalah bencana yang diakibatkan oleh peristiwa atau serangkaian peristiwa yang diakibatkan oleh manusia yang meliputi konflik sosial antarkelompok atau antarkomunitas masyarakat, dan teror.

Cukup menarik bahwa Indonesia tidak memasukkan ke dalamnya adanya potensi bencana karena konflik bersenjata. (pernah ada draft UU tentang pelestarian Cagar Budaya pada masa konflik bersenjata).

Ancaman bencana (dikenal dengan istilah hazard): suatu kejadian atau peristiwa yang bisa menimbulkan bencana.

Risiko bencana: adalah potensi kerugian yang ditimbulkan akibat bencana pada suatu wilayah dan kurun waktu tertentu yang dapat berupa kematian, luka, sakit, jiwa terancam, hilangnya rasa aman, mengungsi, kerusakan atau kehilangan harta, dan gangguan kegiatan masyarakat. 
Mitigasi: "serangkaian upaya untuk mengurangi risiko bencana, baik melalui pembangunan fisik maupun penyadaran dan peningkatan kemampuan menghadapi ancaman bencana".

Pencegahan bencana: adalah serangkaian kegiatan yang dilakukan untuk mengantisipasi bencana melalui pengorganisasian serta melalui langkah yang tepat guna dan berdaya guna.

Kerentanan: adalah keterpaparan terhadap ancaman bahaya. Dalam konteks cagar budaya, kerentanan bersumber dari agar budaya itu sendiri, baik karena lokasinya terhadap sumber bahaya maupun karena sifat khusus secara fisik yang mempengaruhi ketahanannya terhadap ancaman bahaya (cf. UNESCO 2010: 8).

Dalam konteks cagar budaya, pengertian bencana terutama dikaitkan dengan dampak bencana yang dapat mempengaruhi kemerosotan nilai penting dari cagar budaya itu dan aspek lain yang memiliki relevansi, misalnya ekosistemnya.

Risiko didefinisikan sebaga "the chance of something happening that will have a negative impact on our objectives". Setiap saat risiko harus selalu dipertimbangkan bahwa peluang itu dapat terjadi dan akan memberi dampak sebagaimana kita perkirakan. Baik terhadap koleksi, bangunan, struktur, situs maupun kawasan, dan juga terhadap tujuan-tujuan yang kita rancang atas pemanfaatan dan pelindungannya. Dampak risiko itu kita nyatakan dengan sebutan "perkiraan hilangnya nilai penting dari asset cagar budaya (expected loss of value to the heritage asset) ( Pedersoli Jr. dkk, 2016:9-10).

Dengan demikian manajemen risiko adalah segala upaya yang kita lakukan untuk memahami dan menangani berbagai dampak negative terhadap tujuan kita dalam melestarikan cagar budaya. Termasuk di dalamnya adalah melakukan identifikasi, analisis dan evaluasi risiko. Kemudian kita melakukan tindakan untuk menangani risiko itu, misalnya menghindari, menghilangkan atau mengurangi risiko yang tidak bisa kita terima. Termasuk memindahkan risiko ke tempat lain, jika memungkinkannya, misalnya mengalihkan ke perusahaan asuransi untuk mengantisipasi benda-benda hilang dicuri atau rusak.

Risiko bencana (disaster risk) adalah produk dari ancaman bencana (hazard) dan kerentanan (vulnerability). Ancaman bencana (hazard) adalah suatu gejala (misalnya gempa bumi atau banjir) yang memiliki potensi menimbulkan kekacauan dan kerusakan terhadap cagar budaya. Sedangkan kerentanan adalah keterpaparan cagar budaya terhadap bahaya. Ancaman bencana adalah faktor eksternal dari suatu bencana sedangkan kerentanan adalah fakor yang muncul dari dalam cagar budaya sendiri, baik karena lokasi keberadaannya maupun karena sifat intrinsiknya (Gambar 4). 


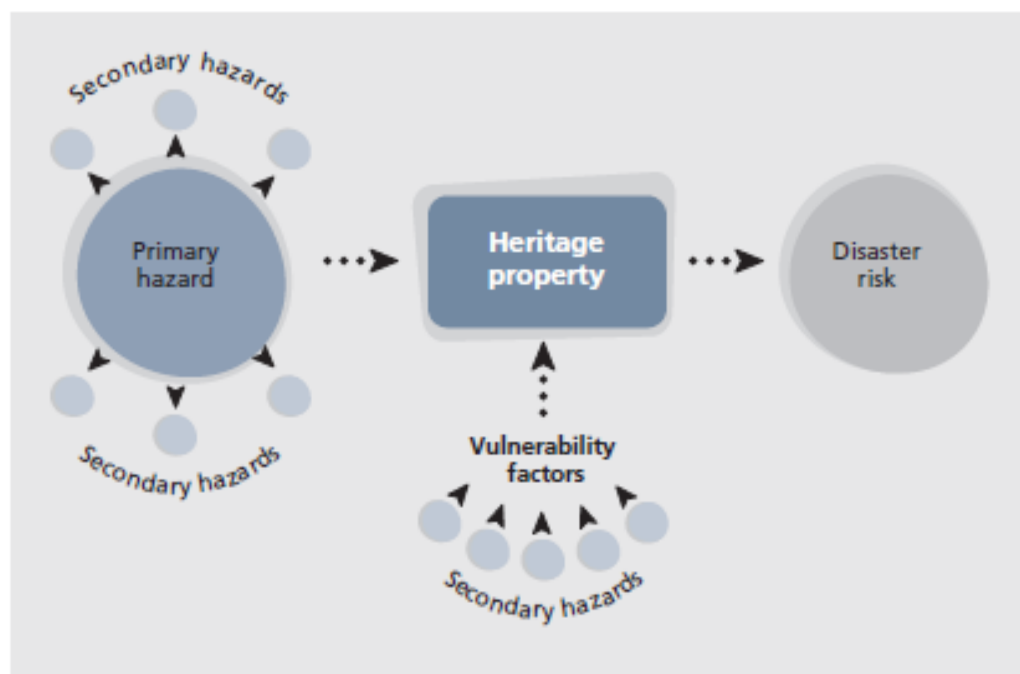

Gambar 4. Ancaman bahaya, kerentanan, dan risiko Bencana Cagar Budaya (Sumber: UNESCO, 2010: 26).

Kegiatan mitigasi (mitigation) dimaksudkan untuk mengurangi risiko kehilangan nyawa dan harta benda dengan cara memperkecil dampak. Agar mitigasi berjalan efektif perlu dilakukan tindakan sebelum bencana terjadi, yaitu melalui analisis risiko, mengurangi dampak risiko dan menghambat terjadinya risiko. Penting untuk diingat bahwa bencana dapat terjadi kapan saja dan di mana saja. Jika kita tidak melakukan persiapan, kosekuensinya bisa fatal. Mitigasi yang efektif membutuhkan pengetahuan tentang risiko setempat, menghadapi pilihan yang sulit dan investasi untuk kesejahteraan komunitas dalam jangka panjang. Tanpa mitigasi, keselamatan jiwa, keamanan dan kemandirian kita terancam bahaya. Mitigasi dapat dikatakan sebagai sebuah mekanisme agar masyarakat dapat menghindari dampak dari bencana yang potensial terjadi. Tindakannya dapat berfokus pada penghindaran bencana, khususnya menghindari penempatan manusia dan harta benda di daerah berbahaya. Termasuk usaha untuk mengendalikan bahaya melalui berbagai pembangunan fasilitas khusus dan penerapan teknologi tertentu (Wijanarko, 2006:25).

\section{Proses mitigasi risiko bencana cagar budaya}

Secara garis besar proses mitigasi risiko bencana dapat dilakukan dalam sejumlah tahapan dengan urut-ututan sebagai berikut.

(1) Dokumentasi dan asesmen aset cagar budaya,

(2) Asesmen ancaman bencana,

(3) Asasmen kerentanan cagar budaya,

(4) Asesmen risiko bencana, dan

(5) Tindakan pencegahan risiko bencana

Dimaksudkan dengan asesmen di sini adalah kegiatan untuk mencari informasi, mengenali dan menilai hasil kegiatan yang telah dicapai dengan maksud untuk mendukung keberhasilan perencanaan yang akan datang. 


\section{Dokumentasi dan Asesmen Aset Cagar Budaya.}

Dalam konteks Indonesia, hal pertama yang perlu diketahui dan dibenahi adalah melalukan asesmen aset, terutama menyangkut jenis-jenis cagar budaya dan jumlahnya untuk setiap kategorinya. Seluruh kekayaan cagar budaya ini perlu didokumentasikan secara komprehensif, termasuk status kepemilikan, pemanfaatannya saat ini, ukuran dan batas-batasnya, kondisi fisiknya dan nilai penting yang terkait dengan kondisi fisik dan makna budaya yang terkendung di dalamnya.

Undang-undang No. 11 Thun 2010 mengelompokkan Cagar Budaya menjadi menjadi 5 jenis, yaitu benda, bangunan, struktur, situs dan kawasan. Berapa jumlah keseluruhannya? Data hingga tahun 2021 menyebutkan jumlah keseluruhannya yang terdaftar adalah 99.460 (http://cagarbudaya.kemdikbud.go.id/rekap), namun rincian mengenai setiap kategori tersebut belum ada. Biasanya rincian yang diberikan menggunakan kategori yang lebih sederhana, yaitu cagar budaya bergerak (movable) yang mengacu kepada objek-objek kecil dan mudah dipindahkan, dan cagar budaya tak-bergerak (imovable) yang dapat mencakup bangunan, struktur, situs dan kawasan. Jumlah yang tertera itu mungkin sekali belum semuanya telah ditetapkan sebagai cagar budaya, tetapi masih berupa daftar objek yang diduga sebagai cagar budaya.

Dalam kaitannya dengan mitigasi risiko bencana, semua jenis cagar budaya itu harus didokumentasikan dengan jelas. Termasuk statusnya sebagai cagar budaya, digunakan untuk fungsi apa, siapa pemilik atau pihak yang menguasainya dan siapa yang kini bertanggungjawab terhadap kekayaan bangsa itu.

Berkaitan dengan penanggungjawab pelestarian, semua cagar budaya harus jelas status peringkatnya, yaitu tingkat kabupaten, tingkat provinsi, dan tingkat nasional. Status peringkat tersebut sangat terkait dengan pembagian kewenangan secara administratif, yaitu masing-masing ada di bawah tanggungjawab Bupati/Walikota, Gubernur, dan Menteri. Di samping itu terdapat kategori yang paling tinggi yaitu warisan budaya dunia (world heritage) yang menjadi tanggungjawab pemerintah Indonesia dengan pengawasan oleh UNESCO. Hal yang sama juga berlaku untuk benda-benda koleksi museum. Khusus koleksi museum mungkin relatif jelas siapa yang harus melakukan pelindungan, kepemilikan dan penanggungjawabnya. Di Indonesia museum-museum dibagi tiga kategori berdasarkan tingkat administrasi pengelolanya, yaitu museum kabupaten, museum provinsi dan museum nasional di samping sejumlah museum swasta.

Adapun untuk jenis cagar budaya yang berada di lapangan, khususnya bangunan, struktur, situs dan kawasan, dokumentasi datanya juga masih harus disusun lebih komprehensif. Salah satu informasi tentang kepemilikannya saja mungkin masih belum tersedia secara memadai, misalnya apakah dimiliki atau dikuasai oleh pemerintah pusat, pemerintah provinsi, pemerintah kabupaten/kota, pribadi, badan hukum, atau masyarakat adat. Bahkan di antaranya mungkin malah tidak terlindungi sama sekali karena ditelantarkan, terutama cagar budaya yang 
berada di wilayah-wilayah pinggiran, di kawasan hutan atau ada di bawah perairan (sungai, danau atau laut).

Dokumentasi cagar budaya tidak hanya menyangkut aspek fisiknya saja, tetapi juga potensi nilainya, baik nilai ekonomi maupun nila budayanya. Nilai ekonomi bisa diukur dari harga jual objek itu sendiri, khususnya jika objek itu menyangkut barang-barang yang lazimnya dikomersialkan di pasar benda-benda seni. Atau kesanggupan para pengunjung untuk membayar (willingness to pay) objek-objek cagar budaya yang menjadi tempat destinasi wisata (baik museum maupun situs atau kawasan). Adapun nilai budaya berkaitan dengan makna historis dan makna-makna lain yang menjadi alasan mengapa benda-benda itu ditetapkan sebagai cagar budaya dan harus dilestarikan. Meskipun harus dipahami pula bahwa pemisahan dua nilai itu tidak lah mudah untuk membedakannya, karena seringkali nilai komersial juga dipengaruhi oleh nilai budayanya. Objekobjek yang terbuat dari logam mulia dan batu mulia misalnya, memiliki nilai komersialnya sendiri, di samping juga nilai estetika. Namun hal yang paling penting dalam konteks mitigasi risiko bencana adalah bahwa salah satu yang penjadi pertimbangan utama adalah nilai penting aspek budayanya. Artinya, risiko bencana harus memperhatikan kemungkinan cagar budaya itu berkurang nilai pentingnya atau bahkan mengalami kehilangan nilai pentingnya sema sekali (misalnya hancur lebur atau hilang/musnah).

Analisis nilai penting harus memperhitungan aspek keutuhan bahan, desain, setting, dan aspek-aspek lain yang dapat mempengaruhi nilai pentingnya. Analisis fisik yang semacam itu dapat dilakukan terhadap koleksi, bangunan, struktur, situs dan kawasan cagar budaya. Sedang aspek nilai penting budaya lazimnya dinilai berdasarkan standar yang berlaku di setiap negara yang bersangkutan. Di Indonesia menggunakan rumusan yang termuat dalam UU No. 11 Tahun 2010 tentang Cagar Budaya, yaitu nilai sejarah, ilmu pengetahuan, pendidikan, agama, dan kebudayaan.

Perlu diingat bahwa ancaman bencana dapat mempengaruhi nilai-nilai penting itu. Salah satu tujuan utama pengelolaan risiko adalah untuk menjaga nilai penting cagar budaya dan keberlanjutannya. Oleh karena itu, perlu dicatatat informasinya yang berkaitan dengan nilai penting itu, yaitu otentisitasnya (authenticity) maupun keutuhannya (integrity), baik dalam aspek bahan, bentuk, pengerjaan, setting dan lainnya (cf. UNESCO 2010:11). Jika dokumentasi yang lengkap tentang asset cagar budaya telah tersedia, maka akan mudah dalam membuat perencanaannya, baik yang berkaitan dengan ketersediaan sumber daya manusianya, fasilitas yang diperlukan maupun kebutuhan anggarannya. Penting untuk diingat bahwa seluruh dokumen tersebut harus disimpan di tempat yang juga aman, namun mudah diakses pada saat diperlukan. 


\section{Pengenalan dan Asesmen Ancaman Bencana terhadap cagar Budaya.}

Hingga kini lembaga pelestari cagar budaya Indonesia belum memiliki peta wilayah rawan bencana yang dikaitkan dengan keberadaan cagar budaya, baik yang dikaitkan dengan ancaman bencana alam, maupun bencana karena ulah manusia. Termasuk kaitan antara lokasi cagar budaya terhadap wilayah dengan indeks multi bencana yang berbeda-beda. Berdasarkan kategorisasi yang dilakukan oleh World Meteorological Organization (WMO) sumber-sumber ancaman bencana (hazards) dirinci sebagai berikut (WMO; ICSU, 2007; cf. UNESCO 2010: 9):

- meteorologikal: berbagai jenis angin rebut, gelombang panas dan petir dan api;

- hidrologikal: banjir, banjir bandang dan tsunami;

- geologikal: gunung api, gempa bumi, pergerakan massa tanah (runtuh, longsor dan bergeser);

- astrofisikal: meteor;

- biologikal: epidemik, hama;

- perubahan iklim: peningkatan frekuensi badai dan kekuatan dampaknya, banjir semburan danau es (glacial lake outburst floods/GLOFs).

- intervensi manusia: konflik bersenjata, kebakaran, polusi, kegagalan atau hancurnya infrastruktur, kerusuhan sosial dan terorisme;

Kategorisasi demikian sesungguhnya tidak sesederhana itu. Dalam kenyataannya, sumber-sumber bencana seringkali tidak berdiri sendiri, sehingga dikenal istilah ancaman bencana primer dan ancaman bencana sekunder. Hujan lebat sebagai akibat perubahan iklim dapat menimbulkan banjir dan banjirnya sendiri dapat menimbulkan tanah longsor. Dalam rangkaian ancaman bencana itu kerusakan cagar budaya bisa disebabkan oleh ancaman bencana primer maupun ancaman bencana sekundernya (lihat Gambar 3).

Informasi tentang kebencanaan perlu dihimpun untuk bisa menganaisis dampak bencana yang pernah terjadi pada masa lampau. Sumber-sumbernya bisa diperoleh dari catatan sejarah, laporan lembaga-lembaga yang berurusan dengan penanggulangan bencana dan tulisan-tulisan dalam bentuk laporan dan karya ilmiah dan lain-lain yang memuat informasi kebencanaan.

Berdasarkan data tersebut dapat diidentifikasikan wilayah-wilayah cagar budaya di seluruh Indonesia beserta luasannya yang memiliki potensi terkena bencana, misalnya gempa bumi, tsunami, letusan gunung api, banjir dan kebakaran. Skala bencana juga perlu diidentifikasi dan dibuat standarisasinya. Badan Nasional Penanggulangan Bencana membuat tiga kateogori, yaitu skala rendah, sedang dan tinggi. Masing-masing kategori itu perlu dibuat definisinya. Pemberian peringkat dapat didasarkan pada kemampuan masyarakat, atau lembaga yang menanganinya, dari skala yang paling rendah bila mampu mengatasinya sendiri hingga yang tertinggi jika membutuhkan bantuan pihak lain untuk mengatasinya.

Gambaran umum indeks risiko bencana di Indonesia saat ini dapat dilihat dari dokumen rencana Nasional Penanggulangan Bencana 2010-2014 yang mencakup 
seluruh wilayah Indonesia. Indek risiko itu dikaitkan dengan bencana gunung api, gerakan tanah dan erosi (Kompas, 2011:20-22; lihat Gambar 1). Data risiko bencana sebagaimana ditampilkan pada peta multi risiko bencana tersebut sebenarnya bisa digunakan untuk pemetaan distribusi cagar budaya yang ada di wilayah-wilayah rawan bencana di Indonesia.

Pihak instansi dapat bekerjasama dengan lembaga yang memiliki ororitas untuk membuat peta serupa untuk kepentingan mitigasi risiko cagar budaya, terutama di wilayah-wilayah dengan indeks risiko bencana yang tinggi. Kita bisa memesan petapeta dengan skala yang mudah dibaca hingga tingkat kabupaten, atau kecamatan, bahkan desa. Hasil kajian risiko bencana pada inaRISK saat ini masih skala $1: 250.000$ dan sedang dalam proses pembuatan data untuk 136 kabupaten/kota dengan skala 1 : 50.000 dan $1: 25.000$ (Benton, 2019). Melalui kerjasama lintas sektor atau lembaga, upaya untuk mengenali secara spesifik tingkat keterbukaannya terhadap sumber-sumber ancaman bencana dapat dilakukan dengan lebih efektif dan efisien.

Berbagai sumber ancaman bencana perlu dianalisis peringkat risikonya. Di Indonesia ada tiga jenis ancaman bencana yang paling sering terjadi, yaitu kebakaran, banjir dan tanah longsor, gempa vulkanik dan belakangan tsunami. Ancaman tsunami terutama di wilayah pantai, gempa vulkanik di wilayah pegunungan dan lembah sekitarnya, banjir dan tanah longsor ada di antara dua wilayah tersebut termasuk wilayah pantai dengan bencana yang khas berupa banjir rob. Tentu saja ancamanancaman risiko bencana itu tidak selalu sama di semua daerah. Setiap jenis ancaman bencana itu perlu dianalisis tingkat kekuatannya dalam menimbukan risiko bencana.

Selama ini Indonesia membuat tiga kategori indeks risiko bencana, yaitu tinggi, sedang dan rendah. Jenis-jenis risiko bencana terhadap cagar budaya bervariasi dari peristiwa katastropik yang berlangsung seketika (seperti gempa bumi dahsyat, banjir, kebakaran, dan konflik bersenjata), maupun yang bersifat perlahan, bertahap dan kumulatif (seperti kimia, fisika, atau biologi). Apapun bentuknya, semuanya dapat mengakibatkan hilangnya nilai penting cagar budaya (Pedersoli Jr. dkk, 2016:10).

\section{Pengenalan dan Asesmen Kerentanan Cagar Budaya.}

Ancaman bencana, baik yang yang bersumber dari kekuatan alam atau oleh intervensi manusia bukanlah satu-satunya yang menimbulkan risiko bencana. Sumber lainnya adalah kerentanan dari agar budaya itu sendiri. Dua aspek yang dapat meningkatkan kerentanan cagar budaya adalah factor lokasi di mana cagar budaya berada atau ditempatkan, dan sifat yang terkandung di dalam cagar budaya itu sendiri.

Lokasi cagar budaya dapat berada di tempat yang berbeda-beda dengan tingkat kerentanan yang berbeda-beda terhadap sumber ancaman bencana yang berbedabeda. Jika sumber bencana berupa banjir atau tsunami, benda-benda koleksi museum yang berada di fitrin, atau di gudang atau di ruang pamer memiliki kerentanan yang rendah dibandingkan dengan banda-benda lain yang berada di luar gedung atau di dekat sungai atau di pesisir pantai. Namun sebaliknya jika sumber bencana itu adalah 
kebakaran karena masalah listrik di gedung museum misalnya, maka tingkat kerentanan jauh lebih tinggi daripada benda-benda yang ada di luar museum.

Masing-masing kategori cagar budaya yang berada di ruang tertutup (museum) maupun di ruang terbuka harus dilengkapi deskripsi yang lengkap. Dengan demikian analisis kerentanan harus dirinci berdasarkan jenis cagar budaya, karena setiap kategorinya memiliki sifat dan kerentanan yang berbeda dalam menghadapi jenis ancaman bencana yang berbeda. Situs dan kawasan cagar budaya mungkin memiliki kesamaan, sehingga unsur-unsur yang dideskripsi juga sama. Misalnya ukuran dan luasannya, morfologi landskapnya, sistem pengelolaannya, sarana dan akses jalan serta manajemen pengunjungnya. Semuanya perlu dicatat dengan lengkap, termasuk posisinya terhadap sumber-sumber ancaman bencana, misalnya sungai, laut, pabrik-pabrik, atau instalasi lain yang punya potensi menjadi sumber ancaman bencana.

Kategori lainnya yaitu bangunan dan struktur cagar budaya yang bersifat individual, karena memiliki kesamaan, juga dapat dibuat sistem dokumentasi yang mirip. Terhadap jenis cagar budaya ini perlu didokumentasikan jenis bahan dan kontruksinya. Berbedaan bahan dan struktur bangunan akan mempengaruhi kerentanannya dalam merespons ancaman bencana.

Benda-benda koleksi museum yang berada di dalam ruang tertutup tentu memiliki sistem dokumentasi yang berbeda. Biasanya untuk mengukur indeks risiko dibuat gambaran skala ruang secara konsetris dari ruang paling kecil, yaitu koleksi di dalam fitrin di museum hingga skala yang semakin luas hingga di luar gedung. Melalui gambar ruang dengan skala luas yang bervariasi dapat di antisipasi dari mana sumber ancaman itu datang dan bagaimanan mengantisipasinya (Pedersoli Jr. dkk, 2016: 49; 58).

Faktor internal lain adalah sifat cagar budaya itu sendiri. Objek-objek cagar budaya pada umumnya akan semakin berkurang daya tahannya terhadap berbagai ancaman bencana karena faktor umur. Semakin tua suatu bangunan dan struktur cagar budaya semakin berkurang kekuatannya untuk merespons berbagai ancaman bencana. Kondisi serupa ini perlu dicatat dengan terinci dalam rangka analisis indek kerentanan. Di samping umur, bahan utama yang digunakan untuk pembuatan cagar budaya juga memiliki pengaruh. Bahan kayu lebih rentan menghadapi ancaman bencana hidrologis, misalnya air hujan atau banjir, atau ancaman biologis dalam bentuk jazad renik, juga rentan pada api. Logam lebih rentan terhadap perubahan cuaca dan air, tetapi kuat menghadapi gempa bumi dibandingan bahan kayu. Koleksi-koleksi museum juga memiliki karakter yang berbeda-beda dalam merespon ancaman bencana. Koleksi lukisan, benda keramik, logam, batu dan terakota memiliki kararakter berbeda-beda. Masing-masing mempunyai kelebihan dan kekurangan dalam menghadapi berbagai jenis ancaman bencana. Teknologi pengerjaan pada saat bangunan itu didirikan bisa jadi belum menggunakan teknologi yang cukup maju untuk bisa bertahan lama, misalnya bangunan-bangunan yang 
didirikan sebelum ada teknologi konstruksi beton tentu akan lebih rentan menghadapi bencana.

Kondisi fisik cagar budaya bisa bertambah tingkat kerentanannya karena ketidak pedulian para pemilik atau lembaga-lembaga pelestari. Hal ini biasanya karena keterbatasan sumberdaya manusia yang terampil untuk merawatnya. Oleh karenan itu kita sering menjumpai kondisi bangunan yang retak-retak atau konstruksi yang rusak, bahkan sebagian atau seluruh atapnya sudah runtuh. Kondisi ini tentu akan semakin memudahkan bangunan itu hancur bila menghadapi bencana gempa bumi atau curah hujan yang tinggi. Kondisi cagar budaya dengan kerentanan ini tidak hanya memiliki risiko untuk runtuh ketika terjadi bencana, tetapi juga dapat mengakibatkan korban manusia yang tertimpa. Aspek lain yang berkaitan dengan kerentanan adalah pemanfaatannya. Khusus untuk kategori bangunan dan struktur, tingkat kerentanan bisa semakin tinggi bila dibiarkan kosong dan tidak dirawat, atau bahkan digunakan dengan cara-cara yang melampaui daya dukungnya.

\section{Asesmen Risiko Bencana.}

Asesmen risiko bencana perlu memperhitungkan risiko-risiko yang mungkin dihadapi oleh setiap jenis cagar budaya jika menghadapi ancaman bencana yang berbeda-beda. Jika hitungan-hitungan sudah diketahui, maka harus diputuskan prioritas penangannya. Baik dalam bentuk peningkatan kualitas dan kuantitas sunmber daya manusianya, maupun upaya pencegahan melalui pembangunan sarana fisik untuk mencegah terjadinya risiko yang tidak diharapkan.

Sebagai contoh, sebuah bangunan candi terbuat dari bata berada di lokasin yang terbuka. Bangunan ini akan selalu terkena hujan dan mungkin akan tergenang dalam periode tertentu secara berulang-ulang. Bahan bata ini lama kelamaan akan ditumbuhi lumut atau jazad renik lain. Jika intensitasnya tinggi maka tingkat kerusakannya akan terus berlangsung hingga kerentanan bangunan ini akan terus meningkat. Contoh-contoh jenis cagar budaya lainnya harus dibuat secara terinci dengan jenis ancaman bencana yang berbeda-beda.

Prioritas mitigasi risiko bencana harus didasarkan pada hasil analisis risiko sebagaimana dicontohkan di atas. Beberapa aspek yang dijadikan pertimbangan adalah:

(1) Probabilitas risiko ketika terjadi bencana. Apakah tinggi, sedang atau rendah. Setiap jenis cagar budaya bisa menghadapi tingkat risiko yang berbeda-beda. Kategorisasi peringkat risiko juga bisa berbeda-beda (cf. Pedersoli Jr. dkk, 2016: 62-66).

(2) Potensi dampak kerusakan. Apakah dampaknya terbatas pada cagar budaya, atau mencakup aspek-aspek lain, misalnya manusia, harta benda, dan infrastruktur. Tingkat keluasan dampak itu perlu dijadikan pertimbangan.

(3) Dampak terhadap nilai penting cagar budaya. Misalnya, suatu situs tertentu dapat memiliki sejumlah komponen yang di dalamnya memuat nilai penting 
yang menjadi dasar mengapa harus dilestarikan. Penilaian terhadap tingkat penurunan nilai penting ini perlu dijadikan dasar petimbangan.

Faktor-faktor lain yang dapat dijadikan pertimbangan untuk menentukan prioritas adalah berdasarkan analisis untung-rugi (cost benefit analysis), khususnya dengan membandingkan biaya yang dikeluarkan untuk melakukan tindakan pencegahan dengan manfaat atau nilai penting yang hendak dipertahankan. Situasi ini tentu akan berkaitan dengan ketersediaan sumber daya manusia dan kemampuan pendanaannya. Prioritas biasanya juga ditentukan berdasarkan prinsip-prinsip umum. Jika itu manusia, maka keselamatan manusia akan menjadi prioritas paling utama. Sedang jika itu cagar budaya prioritasnya adalah nilai pentingnya yang harus dilindungi.

\section{Tindakan Pencegahan Risiko Bencana}

Terdapat alasan mendasar yang perlu diingat mengenai pentingnya tindakan mitigasi bencana dalam rangka pelestarian cagar budaya. Diantara alasan tersebut dapat disebutkan berikut ini (cf. UNESCO 2010:8):

1. Cagar budaya memiliki arti penting sebagai sumber identitas dan kebanggaan nasional dan local karena dapat mempererat persatuan. Setiap Negara memiliki tanggungjawab untuk melestarukannya untuk generasi mendatang. Oleh karena itu para pengelola cagar budaya memiliki tanggungjawab untuk nelindungi nilai pentingnya.

2. Bencana sudah banyak terjadi dan akan terus terjadi. Oleh karena itu cara terbaik untuk menyikapinya adalah dengan melakukan persiapan untuk menghadapi kejadian-kejadian yang tidak dapat dihindari itu.

3. Berbegai bentuk bencana seperti gempa bumi, banjir, kerusuhan sosial dan konflik bersenjata tidak dapat sepenuhnya dicegah, namun upaya mitigasi dapat secara efektif mengurangi dampak yang mungkin akan terjadi.

4. Bencana dapat membawa konsekuensi kehilangan biaya yang amat besar. Oleh karena itu mitigasi merupakan bentuk investasi yang lebih efektif untuk menekan biaya karena dilakukan melalui perencanaan daripada bentuk penanganan pasca bencana yang menelan biaya jauh lebih besar untuk pemulihan dan rehabilitasi.

5. Mengurangi risiko merupakan bentuk pendekatan manajemen yang paling efektif.

Adapun strategi yang dapat digunakan untuk mengurangi risiko bencana (cf. Government of India, 2017: 26; Manas 2-13: 28-29) adalah:

1. Mencegah dan mengurangi ancaman bencana. Bentuk-bentuk tindakannya antara lain: memindahkan sumber api atau bahan yang mudah terbakar untuk mencegah kebakaran; membangun tanggul untuk mencegah dampak banjir atau tsunami; mengatur tata ruang untuk mencegah potensi bencana. 
2. Mengurangi tingkat kerentanan cagar budaya. Cara-cara yang dapat dilakukan antara lain: memindahkan lokasi cagar budaya untuk di tempat yang lebih terlindung dari ancaman langsung sumber bencana; melakukan stabilisasi dan renovasi bangunan yang rawan runtuh; mengganti material yang telah rapuh.

3. Meningkatkan kapasitas sumber daya manusia. Program-program yang dapat dilakukan antara lain: pendidikan dan pelatihan, peningkatan budaya sadar bencana.

4. Memindahkan risiko bencana: menggunakan jasa asuransi untuk mengantisipasi pencurian atau kerusakan.

\section{SIMPULAN DAN SARAN}

Bencana memiliki dampak yang sangat luas, tidak hanya pada keselamatan manusia, kehancuran infrastruktur dan harta benda, tetapi juga kemusnahan cagar budaya dan nilai penting yang terkandung di dalamnya. Namun risiko bencana bisa diperkecil jika ada upaya-upaya yang terencana untuk melakukan pencegahan. Demikian pula cagar budaya yang berada di wilayah dengan indek risiko bencana tinggi juga bisa diminimalisasi dampaknya, yaitu dengan melakukan mitigasi risiko bencana. Jika prinsip-prinsip mitigasi diikuti dengan sungguh-sungguh dan komitmen tinggi maka potensi bencana yang dapat menghancurkan kekayaan warisan budaya bangsa Indonesia dapat kendalikan dan diminimalisasi secara maksimal.

Mengingat Negara Indonesia merupakan wilayah dengan risiko bencana sangat tinggi, kiranya perlu segera dituntaskan persiapan untuk melakukan tindakan penanggulangan bencana cagar budaya. Semakin cepat disiapkan semakin kecil peluang bangsa ini menghadapi risiko bencana yang dapat merusak warisan budaya kita dan dapat menyelamatkan dana dengan mengalihkannya untuk tujuan pencegahan, alih-alih untuk melakukan kegiatan penyelamatan tanggap darurat, rekonstruksi, dan rehabilitasi pasca bencana yang nilainya jauh lebih besar.

Pada saat ini kemampuan kita untuk menghadapi risiko bencana sesungguhnya belum memadai. Dokumen legal yang memiliki dampak implementasi yang luas dan efektif, seperti yang telah dimiliki pemerintah India, belum tersedia. Kita perlu segera merampungkan program awal dengan merampungkan penyusunan pedoman penanggulangan bencana yang rencananya diberi tajuk Cagar Budaya Tangguh Bencana. 


\section{DAFTAR PUSTAKA}

Abbas, Novida (ed). 2016. Liangan: Mozaik Peradaban Mataram Kuni di Lereng Sindoro. Yogyakarta: Kepel Press.

Antar, Yori. 2018. Belajar dari Kebakaran Bangunan Cagar Budaya dan Rumah Adat.

Asman, Aulia; Eri Barlian, Dedi Hermon, Indang Dewata, Iswandi Umar. Mitigation and Adaptation of Community using AHP in Earthquake DisasterProne Areas in Pagar Alam City - Indonesia. International Journal of Management and Humanities (IJMH) ISSN: 2394-0913, Volume-4 Issue-9, May 2020.

Balai Pelestarian Peninggalan Purbakala Jawa Tengah. 2006. Java Earthquake, 27 Mei 2006. The Center for Cultural Heritage Preservation Central Java \& Kamakura UNESCO Association in Japan.

Damardono, Haryo. 2011.Tata Ruang Masih Disepelekan. Dalam Laporan Khusus Kompas: Bencana Mengancam Indonesia. Jakarta: Penerbit Buku Kompas, h. 44-48.

Damayanti, Doty. 2011. Manajemen Bencana Mendorong Mitigasi Berbasis Risiko. Dalam Laporan Khusus Kompas: Bencana Mengancam Indonesia. Jakarta: Penerbit Buku Kompas, h. 33-36.

FEMA. 2005. Risk Assessment: A How-To Guide to Mitigate Potential Terrorist Attacks Against Buildings.

Maeno, Fukashi dkk. 2019. Pattern and a Long-Term Magma Discharge Rate over the Past 100 Years at Kelud Volcano, Indonesia. Journal of Disaster Research,Vol.14 No.1, 2019, p. 27-39.

Geertz, C. 1983/1963. Involusi Pertanian: Proses Perubahan Ekologi di Indonesia (terj). Jakarta: Bhratara.

Genthong, Aryo Wisanggeni. 2011. Sampai Kapan Kita Abai. Dalam Laporan Khusus Kompas: Bencana Mengancam Indonesia. Jakarta: Penerbit Buku Kompas, h. 10-14.

Government of India. 2017. National Disaster Management Guidelines for Cultural Heritage Sites and Precincts. New Delhi: National Disaster Management Authority, NDMA Bhawan

Harijono, Try. 2011. Mitigasi Bencana: tenaga Terlatih Diabaikan. Dalam Laporan Khusus Kompas: Bencana Mengancam Indonesia. Jakarta: Penerbit Buku Kompas, 29-32.

Hidayati, Sri; Ahmad Basuki; Kristianto; and Iyan Mulyana. 2009. Emergence of Lava Dome from the Crater Lake of Kelud Volcano, East Java. In Jurnal Geologi Indonesia, Vol. 4 No. 4 Desember 2009: 229-238.

Isworo, Brigita L. 2011. Perubahan Iklim Perlukah Menunggu Bencana Besar? Dalam Laporan Khusus Kompas: Bencana Mengancam Indonesia. Jakarta: Penerbit Buku Kompas, 55-60.

Isworo, Brigita L. 2011. Bencana Kebumian Kita Tak Semestinya Pasrah. Dalam Laporan Khusus Kompas: Bencana Mengancam Indonesia. Jakarta: Penerbit Buku Kompas, h. 23-28.

Kompas, 2011. Luputan Khusus Ekspedisi Cincin Api: Toba Mengubah Dunia (15 Oktober 2011). 
Leksono, Ninok. 2011. Dalam Keniscayaan Daulat Alam. Laporan Khusus Kompas. Bencana Mengancam Indonesia. Jakarta: Penerbit Buku Kompas, 3-9.

Manas, Murty. 2013. Heritage And Resilience Issues And Opportunities For Reducing Disaster Risks. UNESCO, MARSH, ICCROM.

Oppenheimer, Stephen. 2010. Eden of the East: Benua yang Tenggelam di Asia Tenggara (terjemahan). Jakarta: Ufuk Press.

Oesman, Osrifoel. 2018. "Pemeliharaan bangunan cagar budaya masa kolonial untuk pemanfaatan museum" dalam Seminar dengan tema Belajar dari Kebakaran Bangunan Cagar Budaya dan Rumah Adat. Diselenggarakan oleh IAAI.

Panjaitan, Berton SP. 2019. Manajemen Penanggulangan Bencana di Bangunan cagar Budaya dan Museum. (ppt. tidak diterbitkan). Diskusi Penanggulangan Bencana di Bangunan Cagar Budaya dan Museum. Diselenggarakan di Jakarta, 28 Agustus 2019 oleh Balai Konservasi Cagar Budaya, Pemda DKI Jakarta).

Pedersoli Jr, Jose Luiz dkk. (2016). A Guide to Risk Management of Cultural Heritage. ICCROM, Government of Canada, Canadian Conservation Institute.

Pratomo, Indyo. Klasifikasi gunung api aktif Indonesia, studi kasus dari beberapa letusan gunung api dalam Sejarah. Jurnal Geologi Indonesia, Vol. 1 No. 4 Desember 2006: 209-227.

Sampurno dan Bandono. 1980. Peranan geologi dalam pertumbuhan dan kehancuran kerajaan-kerajaan lama di Jawa, dengan contoh kerajaan Majapahit. Ikatan Ahli Geologi Indonesia.

Schrieke, B.J.O. 1959/1941. The End of Classical Hindu-Javanese Culture in Central Java: A Study of Economic Geography. Dalam Indonesian Sociological Studies (Part Two). 's-Gravenhage: N.V. Uitgeverij W. van Hoeve, h. 285-301.

Toha, Budianto. 1985. Fenomena Alam Penyebab Runtuhnya Candi Sambisari di Kalasan, Slemat, Jawa Tengah. Dalam PIA, h. 1043-1054. Jakarta: Pusat Penelitian Arkeologi Nasional.

Undang-Undang Republik Indonesia Nomor 24 Tahun 2007 Tentang Penanggulangan Bencana

UNESCO, 2010. Managing Disaster Risk for World heritage. UNESCO / ICCROM / ICOMOS / IUCN,

Wahyudi, M. Zaid. 2011. Perubahan Iklim: Berharap Iklim Akan kembali Normal. Dalam Laporan Khusus Kompas: Bencana Mengancam Indonesia. Jakarta: Penerbit Buku Kompas, h. 51-54.

Wibisono, Sonny. 2017. Bencana \& Peradaban Tambora 1815. Jakarta: Pusat Penelitian Arkeologi Nasional.

Winardi, K. dkk. 2006. Gempa: Jogja, Indonesia dan Dunia. Jakarta: PT. Gramedia Majalah.

WMO. Disaster Risk Reduction (DRR) Programme. Geneva, World Meteorological Organization. http://www.wmo.int/pages/prog/drr/ 